\title{
Retraction Note to: Text mining and network analysis of molecular interaction in non-small cell lung cancer by using natural language processing
}

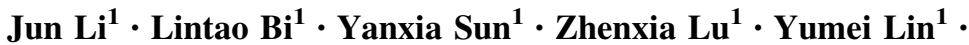 \\ Ou Bai $^{2} \cdot$ Hui Shao ${ }^{1}$
}

Published online: 18 August 2015

(C) Springer Science+Business Media Dordrecht 2015

Retraction Note to: Mol Biol Rep (2014) 41:8071-8079

DOI 10.1007/s11033-014-3705-5

The Publisher and Editor retract this article in accordance with the recommendations of the Committee on Publica tion Ethics (COPE). After a thorough investigation we have strong reason to believe that the peer review process was compromised.

The online version of the original article can be found under doi:10.1007/s11033-014-3705-5.

Ou Bai

oubai16@163.com

1 Department of Hematology and Oncology, China-Japan

Union Hospital of Jilin University, Changchun 130031, Jilin,

People's Republic of China

2 Tumor Center, Jilin University First Hospital, No. 261

Xinminda Street, Changchun 130021, Jilin,

People's Republic of China 